\title{
Integration of Psychodrama and Transactional Analysis Methods in psychoeducational work with school-age children in Russia
}

\author{
(C) 2015 Marina Solomonovna Sokovnina and Viktor Nikolayevich \\ Aleshin
}

\begin{abstract}
Beginning with a comparison of the concepts and methods of psychodrama and transactional analysis, the authors identify similarities and present their experiences of combining these approaches in order to conduct workshops for $5^{\text {th }}$ grade (11-12 years) students within the Russian educational system. They provide their rationale for this work, details of the content of the training and an example of the work of the students in the form of an agreement on cooperation between students and teachers. They provide an analysis of the reported emotions during lessons for 78 students compared to 38 within control groups, showing increased positive emotions and decreased negative emotions for those in the transactional analysis/psychodrama lessons. They conclude that the role-play method used was more effective than traditional educational methods within Russia for the development of autonomy, motivation and involvement of students.
\end{abstract}

\section{Keywords}

transactional analysis, psychodrama, educational transactional analysis, efficiency estimation of transactional analysis, Redecision school.

Editor's Note: this paper is an amended version of one previously published by Aleshin \& Sokovnina (2012) in the Proceedings of the XVI International Scientific and Practical Conference and is reproduced here with the kind permission of the Chief Editor of the Proceedings, N M Shingayev, Head of the Psychology Department of the St Petersburg Academy of Postgraduate Education.

It is common practice to use group work including role-playing when applying approaches such as psychodrama and transactional analysis within educational settings. The authors of this paper initially used psychodrama and TA separately and gradually introduced elements of the other approach into their work. Their experiences were that such a combination provided additional resources for resolution of personal problems and for educational development. They decided, therefore, to analyse the differences and similarities of the two approaches in order to support practice with theory, and to find the contact points between the theories for a better understanding of the principles for combination.

\section{Historical Background}

Historically it has been evident that the two approaches have contributed to each other, and that the creators - Jacob Moreno and Eric Berne - were developing their ideas during the same period. According to biographer René $F$. Marineau (1989/2001), professionals from different fields gathered in 1942 in New York at the Institute of Sociometry, organized by Moreno, and "people like Fritz Perls, S. H. Foulkes and Eric Berne participated in Friday-night sessions" (p. 15). The German psychodramatist Grete Leutz (2008) noted that these sessions influenced the participants of the meetings to include role-playing techniques into their practice, and she believes that Eric Berne, influenced by these meetings, has featured transactional games in his theory.

Berne (1957/1991) described the advantages of psychodrama as follows: "In psychodrama one can replay severe emotional disturbances, which allows the subject to fully express his (sic) feelings and in such a way to realize his accumulated fears and faults." (p. 279)

\section{Comparison of the Concepts of Psychodrama and TA}

The notions introduced by Moreno and Berne were close, including game, spontaneity, creativity, interaction, etc. Some of their practical approaches to psychotherapeutic work are also similar, as can be seen in Table 1. 


\begin{tabular}{|c|c|c|}
\hline Approach & Psychodrama & Transactional Analysis \\
\hline $\begin{array}{l}\text { Goal of } \\
\text { Therapy: }\end{array}$ & $\begin{array}{l}\text { Kipper (1986/1993) referred to awakening of } \\
\text { spontaneity, which is expressed in a creative } \\
\text { act, or the manifestation of a certain } \\
\text { behavioural pattern in the here and now } \\
\text { situation; also that Moreno correlated lack of } \\
\text { spontaneity with emotional illness, so the goal } \\
\text { of psychotherapy was to teach spontaneity }\end{array}$ & $\begin{array}{l}\text { Stewart \& Joines (1987/1996) refer to Berne's } \\
\text { concept of autonomy as defined by three } \\
\text { capacities - awareness, spontaneity and } \\
\text { intimacy, commenting that this needs release } \\
\text { or recovery of those three human qualities. }\end{array}$ \\
\hline $\begin{array}{l}\text { Definition of } \\
\text { spontaneity }\end{array}$ & $\begin{array}{l}\text { Spontaneity as a key concept in Moreno's } \\
\text { theory does not mean a reactive action, or lack } \\
\text { of control, or rashness; it implies the ability to } \\
\text { move in a given direction, and hence it is not } \\
\text { alien to self-control. (Kipper 1986/1993) }\end{array}$ & $\begin{array}{l}\text { Spontaneity is understood as a capacity to } \\
\text { choose from a full range of options in feeling, } \\
\text { thinking and behaving (Stewart and Joines } \\
\text { 1996) }\end{array}$ \\
\hline Tasks/ steps & $\begin{array}{l}\text { 1. Facilitate an expression of pent-up } \\
\text { feelings } \\
\text { 2. Contribute to gaining of insight } \\
\text { 3. Help a client to create new and more } \\
\text { effective behaviours } \\
\text { 4. 4. Reveal unexplored possibilities for } \\
\text { conflict resolution }\end{array}$ & $\begin{array}{l}\text { 1. Clarify the problem } \\
\text { 2. Verbalize the desired result } \\
\text { 3. Develop understanding of the } \\
\text { mechanisms of personal script behaviour } \\
\text { 4. Bring a client to re-evaluation of early } \\
\text { decisions and making of new decisions } \\
\text { 5. 5. Consolidate new behaviours through } \\
\text { practice }\end{array}$ \\
\hline
\end{tabular}

Table 1. Similar elements in the conceptual bases of psychodrama and TA

\section{Comparison of the Methods in Psychodrama and TA}

From the authors' viewpoint, one of the branches of TA - the Goulding \& Goulding (1997) redecision school - is the closest to the method of psychodrama. Our comparative analysis is shown in Table 2. We concluded on the basis of our theoretical study and our own practical experiences that the two approaches were similar and compatible and could therefore be applied together in practice.

\section{Practical Application}

We decided that one of the authors would combine TA and psychodrama with $5^{\text {th }}$ grade school students (ages 11-12) during a workshop intended to support a healthy process of acceptance of the new learning environment and the building of new relationships in their group and the development of emotional attachments. Due to the peculiarities of the educational system in Russian secondary schools, fifth grade students change to a different system of education and have to adjust and learn new communication skills and develop new relationships with other teachers. In Grades 1-4, basic subjects are taught by one teacher in one room, with pupils moving to different rooms and different teachers only for gym, music, technology and manual skills. From the $5^{\text {th }}$ grade, a cabinet style of education is used so that each academic subject is held in a specially equipped classroom with its own teacher. Some of the school requirements and expectations from the students also change. There are new subjects in the programme. The rotation of students in parallel classes is often done, in order to create learning groups of students with similar levels of development and academic progress. Because of this, the processes of group dynamics and formation of study groups occurs.

These changes of the learning environment, as well as the natural processes of childhood development, make it necessary to revise explicit and implicit agreements and contracts, including negotiable and non-negotiable rules of behaviour at school. Traditionally, however, such revision is not conducted and students are simply ordered to follow the written rules of behaviour in the school statutes. This contributes to the development of passivity of students and to the emergence of psychological games between teachers and students. 


\begin{tabular}{|c|c|c|c|c|}
\hline \multirow{2}{*}{ Stages } & \multicolumn{2}{|c|}{ The description of the methods at different stages of their implementation } & \multirow{2}{*}{ Similarities } & \multirow{2}{*}{ Differences } \\
\hline & Psychodrama & TA Redecision school & & \\
\hline $\begin{array}{l}\text { 1st stage of warming } \\
\text { up / preliminary phase }\end{array}$ & $\begin{array}{l}\text { Disclosure of the group members and a } \\
\text { protagonist is supported by warming up } \\
\text { techniques }\end{array}$ & $\begin{array}{l}\text { The disclosure of members is provided } \\
\text { through a focus on creating a safe } \\
\text { atmosphere by means of contracting, } \\
\text { rules, protection, paying attention to } \\
\text { group dynamics. }\end{array}$ & $\begin{array}{l}\text { The importance of creating } \\
\text { conditions for self-disclosure and } \\
\text { authenticity in working on problems } \\
\text { is recognized. }\end{array}$ & $\begin{array}{l}\text { A group contract gives an opportunity } \\
\text { to declare individual requests } \\
\text { concerning safety in the group. }\end{array}$ \\
\hline $\begin{array}{l}2 \text { Clarification of } \\
\text { problems and desired } \\
\text { results }\end{array}$ & $\begin{array}{l}\text { A vague image of the result or the } \\
\text { absence of positively formulated result } \\
\text { are possible. }\end{array}$ & $\begin{array}{l}\text { Focus on contracting about outcome } \\
\text { client wants to achieve and specifying } \\
\text { the desired changes in three areas - } \\
\text { feeling, thinking, behaviour. }\end{array}$ & $\begin{array}{l}\text { In both approaches action is } \\
\text { preceded by discussion and } \\
\text { clarification of the problem. }\end{array}$ & $\begin{array}{l}\text { Clear contract guarantees results to } \\
\text { a greater extent, but requires greater } \\
\text { readiness of client. For clients who } \\
\text { 'don't feel their needs', the looser } \\
\text { contracting may be more } \\
\text { appropriate. }\end{array}$ \\
\hline $\begin{array}{l}\text { 3. Techniques for } \\
\text { deciding who works } \\
\text { when. }\end{array}$ & 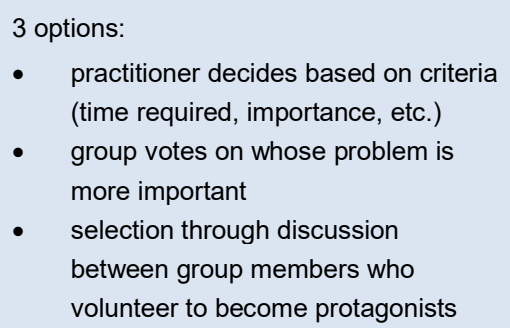 & $\begin{array}{l}\text { Techniques are used simultaneously: } \\
\text { - client's willingness (the explicit } \\
\text { expression of desire to do the work } \\
\text { now) } \\
\text { - group rules that minimize } \\
\text { competitive processes in } \\
\text { establishing order of working }\end{array}$ & $\begin{array}{l}\text { There are recommended rules or } \\
\text { procedures for selection of the } \\
\text { protagonist. }\end{array}$ & $\begin{array}{l}\text { TA has more focus on protection; } \\
\text { with group voting clients may feel } \\
\text { pressured or not important: with } \\
\text { group discussion problems are } \\
\text { actualised for all but may not be dealt } \\
\text { with. }\end{array}$ \\
\hline $\begin{array}{l}4 \text { Enactment and its } \\
\text { peculiarities }\end{array}$ & $\begin{array}{l}\text { Enactment is used for a wide variety of } \\
\text { intrapsychic and interpersonal problems. }\end{array}$ & $\begin{array}{l}\text { Enactment is primarily aimed at work } \\
\text { with the impasses. Portrayed elements } \\
\text { of the scene represent the primal scene } \\
\text { or conditions of the impasse formation, } \\
\text { or significant figures or symbols on which } \\
\text { the content of the impasse is projected. }\end{array}$ & $\begin{array}{l}\text { Both approaches use "enactment" of } \\
\text { the problem to facilitate client's } \\
\text { expression of feelings, reflection, and } \\
\text { to stimulate insight in the area where } \\
\text { the problem is contained. }\end{array}$ & \\
\hline $\begin{array}{l}5 \text { Specific aspects of } \\
\text { the dialogue }\end{array}$ & $\begin{array}{l}\text { Dialogue between real persons is used, } \\
\text { as well as between almost any elements } \\
\text { of client's personality. }\end{array}$ & $\begin{array}{l}\text { Dialogue between "real" individuals, ego } \\
\text { states, roles, needs is used. }\end{array}$ & $\begin{array}{l}\text { The use of "externalization" - bringing } \\
\text { the inner dialogue out. }\end{array}$ & $\begin{array}{l}\text { Psychodrama allows the inclusion of } \\
\text { various elements of the problem, and } \\
\text { relevant hypotheses are put forward } \\
\text { during the work. }\end{array}$ \\
\hline
\end{tabular}




\begin{tabular}{|c|c|c|c|c|}
\hline \multirow{2}{*}{ Stages } & \multicolumn{2}{|c|}{ The description of the methods at different stages of their implementation } & \multirow{2}{*}{ Similarities } & \multirow{2}{*}{ Differences } \\
\hline & Psychodrama & TA Redecision school & & \\
\hline $\begin{array}{l}6 \text { Changes expected } \\
\text { in a client }\end{array}$ & $\begin{array}{l}\text { 1. Catharsis } \\
\text { 2. Insight (realisation) } \\
\text { 3. New ways of behaving, expanding } \\
\text { role repertoire (Aleshin 2009) }\end{array}$ & $\begin{array}{l}\text { Catharsis of unexpressed feelings as an } \\
\text { essential but intermediate phase on a } \\
\text { way to redecision, which in turn leads to } \\
\text { more behaviour options. }\end{array}$ & $\begin{array}{l}\text { Expression of feelings, } \\
\text { understanding problem, new } \\
\text { behaviours; as new behaviours arise } \\
\text { via redecision, we can assume they } \\
\text { are the latent, unaccounted phase in } \\
\text { psychodramatising of problems. }\end{array}$ & $\begin{array}{l}\text { TA additionally uses the concept of } \\
\text { racket feelings to ensure catharsis o } \\
\text { genuine feelings. }\end{array}$ \\
\hline $\begin{array}{l}\text { 7. Necessity to work } \\
\text { with the primal scene }\end{array}$ & $\begin{array}{l}\text { The true essence of things (events) is } \\
\text { revealed only when they appear in their } \\
\text { original context. Change of context } \\
\text { changes the contents of the things. }\end{array}$ & $\begin{array}{l}\text { The importance of identifying the early } \\
\text { scene and stimulating client to change } \\
\text { the decision made at that moment. }\end{array}$ & The importance of the context. & $\begin{array}{l}\text { In redecision school the notion of } \\
\text { primary context is narrower. }\end{array}$ \\
\hline 8 Accuracy & $\begin{array}{l}\text { "It is quite important for both a therapist } \\
\text { and his (sic) patients to provide specific } \\
\text { information during a role-playing session." } \\
\text { ((Kipper, 1986/1993, p. 22) }\end{array}$ & $\begin{array}{l}\text { TA and redecision school put forward a } \\
\text { similar requirement. }\end{array}$ & $\begin{array}{l}\text { Concurrence of the working } \\
\text { methods. }\end{array}$ & \\
\hline 9 Temporal shifts & $\begin{array}{l}\text { The past or the future are brought into the } \\
\text { present. }\end{array}$ & $\begin{array}{l}\text { The client shifts over the time } \\
\text { symbolically. }\end{array}$ & $\begin{array}{l}\text { The client speaks of past events in } \\
\text { the present tense. }\end{array}$ & \\
\hline $\begin{array}{l}10 \text { Factors used for } \\
\text { an enactment of } \\
\text { problem situation or } \\
\text { an issue }\end{array}$ & $\begin{array}{l}\text { The action situation is created through the } \\
\text { scene, the elements of personality are } \\
\text { modelled by participants and/or by the } \\
\text { client. }\end{array}$ & $\begin{array}{l}\text { The imagined action situation can be } \\
\text { created with assistance of group } \\
\text { members, by the client using changing of } \\
\text { chairs, or in the client's imagination }\end{array}$ & $\begin{array}{l}\text { Creating an action situation, related } \\
\text { to the problem, stated by the client. }\end{array}$ & \\
\hline $\begin{array}{l}\text { 11. The use of } \\
\text { 'Focusing' }\end{array}$ & $\begin{array}{l}\text { Therapy by means of clinical role-playing } \\
\text { games uses a selective amplification } \\
\text { (focusing). }\end{array}$ & $\begin{array}{l}\text { Practitioner can use the early decision } \\
\text { focusing method in order to stimulate a } \\
\text { client to redecide. }\end{array}$ & The procedural approaches coincide. & \\
\hline
\end{tabular}




\begin{tabular}{|c|c|c|c|c|}
\hline \multirow{2}{*}{ Stages } & \multicolumn{2}{|c|}{ The description of the methods at different stages of their implementation } & \multirow{2}{*}{ Similarities } & \multirow{2}{*}{ Differences } \\
\hline & Psychodrama & TA Redecision school & & \\
\hline $\begin{array}{l}\text { 12. The importance } \\
\text { of the expression of } \\
\text { feelings for healing }\end{array}$ & $\begin{array}{l}\text { "Insight alone usually does not heal. } \\
\text { Healing occurs when emotions are } \\
\text { ventilated and accepted "(Kipper, } \\
\text { 1986/1993, p. 269) }\end{array}$ & $\begin{array}{l}\text { It is believed that feelings that were not } \\
\text { expressed in the primal scene block the } \\
\text { process of redecision, so the expression } \\
\text { of feelings is essential. }\end{array}$ & The conceptual approaches coincide. & \\
\hline $\begin{array}{l}13 \text { The ritual of } \\
\text { assuming and } \\
\text { shedding the roles }\end{array}$ & $\begin{array}{l}\text { Practitioner regulates and makes sure } \\
\text { participants have left the roles they had } \\
\text { played } \\
\text { - by using psychodrama techniques } \\
\text { (now you are not .... you are .......) } \\
\text { - by leaving the stage }\end{array}$ & $\begin{array}{l}\text { Practitioner regulates de-role of the client } \\
\text { - through finishing of the dialogue on } \\
\text { the initial chair } \\
\text { - saying goodbye to imaginary } \\
\text { figures } \\
\text { removing of conditions and things } \\
\text { of an imaginary situation from the } \\
\text { 'stage' } \\
\text { leading the client out of 'time travel' } \\
\text { using the elements of suggestion }\end{array}$ & $\begin{array}{l}\text { Both methods recognize the } \\
\text { importance of closing - for clients to } \\
\text { leave played roles and the scene. }\end{array}$ & $\begin{array}{l}\text { The differences in the rituals are not } \\
\text { a matter of principle. }\end{array}$ \\
\hline $\begin{array}{l}\text { 14. The closing } \\
\text { stage / Sharing } \\
\text { Protection of the } \\
\text { client }\end{array}$ & $\begin{array}{l}\text { Protection is realized through the rule that } \\
\text { participants focus on their personal } \\
\text { experience (talk about themselves and not } \\
\text { about protagonist) (Moreno, 1998) }\end{array}$ & $\begin{array}{l}\text { Protection is maintained by a group } \\
\text { contract, established at the beginning of } \\
\text { the work, for 'l' messages, no judgmental } \\
\text { statements, etc. }\end{array}$ & $\begin{array}{l}\text { The importance of specific protection } \\
\text { for a client-protagonist during sharing } \\
\text { is taken into account. }\end{array}$ & $\begin{array}{l}\text { The same phenomenon is describec } \\
\text { in different terms. }\end{array}$ \\
\hline $\begin{array}{l}\text { 15. The necessity of } \\
\text { sharing - the } \\
\text { feedback from the } \\
\text { group }\end{array}$ & Sharing is carried out on a mandatory basis. & $\begin{array}{l}\text { Clients 'pass' at the request of the } \\
\text { working client (the protagonist) if } s / \text { he is } \\
\text { not ready to listen. }\end{array}$ & $\begin{array}{l}\text { The importance of sharing (the } \\
\text { feedback) is recogniszed. }\end{array}$ & TA allows exceptions. \\
\hline
\end{tabular}


We concluded that 'play' methods would be an effective way of providing group educational work for these students. We saw this as being within the 'accommodating' quadrant in Kolb's (1984) experiential cycle concept, because this provides action first followed by thinking stimulated by the newly acquired experience and is therefore most relevant to the age characteristics of these students.

Traditionally, Russian methods of education and development begin in Kolb's 'converging' quadrant, with an offering by the teacher of information on a rational level. This creates an imbalance towards cognitive-rational approaches based on conceptual thinking. Playing methods are the most effective way of relationship and personality development in group educational work with school students, since, in our opinion, these methods refer to the 'accomodating' quadrant in the experiential cycle concept of Kolb. This is due to the fact that learning through playing activity, where action comes first and thinking is stimulated by the newly acquired experience, is most relevant to age characteristics of the children. At the same time, other methods of education and development (support), traditionally adopted in Russia, where the educational learning cycle organized by a teacher begins with the offering of information on a rational level ('converging' quadrant in the Kolb experiential cycle concept) are used more often. It creates an imbalance towards cognitiverational approaches based on conceptual thinking.

\section{Workshop Arrangements}

The training workshop was run for six classes, in five of which the effective diagnostics were conducted. One class was correctional, containing children with difficulties in learning and behaviour. Class sizes were usually $25-30$ people, with only 15 in the correctional class. During the training, the children in each class were subdivided into two groups, and one of these groups moved with the second teacher to another room. The membership of the subgroups remained unchanged, and each subgroup studied with only one teacher.

In both groups, the training was conducted according to the same scenario which had been discussed before each class by the authors (both employees of the school - an educational psychologist and an assistant psychologist). The work was financed from the state budget.

The training programme and its conduct were agreed with the school administration. Parental consent was collected in a written form. Children participated in activities on a voluntary basis, having been advised that they had the right to refuse to participate in the lessons. One child out of 81 refused to participate.
The control group comprised another class of 19; these were involved in the diagnostic research process but were not given sessions based on TA and/or psychodrama. Instead they were given additional classes in general school subjects during the times of the TA/psychodrama (TAP) sessions.

\section{Content of the Training}

The following is an outline of how we combined TA and psychodrama within the workshop.

The Preparatory Stage

The rules and the plot of the game were explained and roles were distributed. Each child chose what teacher's role they would play (a teacher of Mathematics, Physical Education, etc.). Then children made their badges, where they wrote their first name and patronymic (as teachers are traditionally called by name and patronymic) and the name of the school subject which they conducted. Badges were used for the ritual of assuming and leaving a role.

The Headteacher Election

Within the role-play, children in the role of teachers elected the headteacher by secret voting from amongst candidates who were those who had expressed a wish to take on the role.

The Pedagogical Council Rules

Acting as a Pedagogical Council, the children as teachers developed the rules of interaction between teachers at staff meetings. The purpose of this was to give them an experience of influencing the group rules.

The Pedagogical Council: Giving the marks Acting as the Pedagogical Council, the children in the roles of the teachers gave the final marks for academic subjects per trimester. This part of the game helped the students to understand teachers' difficulties with decision making while giving marks, and teachers' motivation in evaluating; this was intended to contribute to reduction of negative emotions in teacher-student interactions.

\section{The Contract}

In another case, children in a similar role-playing game developed school rules both in the role of students and in the role of a teacher, which contributed to the acceptance of the school rules. The game consisted of two parts. In the first part, a group of 'students' developed a list of needs and expectations of what they would like to receive from the teacher in order to learn effectively, and a list of responsibilities of what they were ready to do for their education. The second group of 'teachers' developed lists of items of what they required from students and items of what they should and were 
willing to do in order to contribute to students' learning. In the second part dialogue took place and the lists were compared, and there was a joint discussion under the guidance and control of the leader. In both cases, playing used psychodrama techniques of role reversal, role-taking, soliloquy, dialogue, doubling. At the same time, in both cases TA concepts were used as well. In the first example TA understanding of effective and ineffective transactions was applied for the construction and correction of transactions between the participants. In the second case the concept of contract was used and the balance of the school rules, developed by the participants, was considered in terms of their response to the psychological needs and with regard to the balance of the participants' contribution. TA concepts were used in these cases also to conceptualise the understanding of the role play process and its resulting effect.

It was considered, in particular, that even the 'played' discussion of the rules by the participants of the educational process would stimulate the formation of the Adult ego state and personal autonomy and encourage the taking of responsibility, such as for example for the success in learning and for the received marks. In the result of the second game the text of the contract between students and teachers was created. The game ended with signing of the contract between students and teachers who conducted the lesson; stroking for the good work during the training and for the specific achievements. Strokes were given as an oral public recognition of the achievements, as well as and in the form of certificates and letters of appreciation to the students for their success. The text of the contract is given in Appendix A.

\section{Evaluation}

Training impact was evaluated through two methods: student yes/no responses to a listing of 18 emotions that might have been felt during classes, and a limited amount of qualitative feedback through Vopel's (1993/2000) sentence-completion activity "What I have learned" (p. 152). In both cases confidentiality was promised.

Students in the control group also responded to the list of emotions, based on their reactions during the lessons traditionally taught in school, such as languages, literature, geography, history, art, social science, biology, sport, life skills, computer science, technology (e.g. design, modelling, cooking, sewing).

Since the work was carried out by two teachers, the statistics of each teacher's groups were at first considered separately, in order to analyse additionally whether there was an impact of the teacher's working style and personality on the effectiveness of the lessons. Scores in each teacher' groups were compared with the answers of the students from the control sample.

80 participants of the experimental group and 19 participants of the control group took part in the assessment. 2 of the completed protocols were not valid, so the statistics are based on 78 completed protocols.

\section{Results}

The resulting data is shown in Tables 3 and 4, presented in percentages in order to make it possible to compare groups containing a different number of members. In addition, the results of the correctional class students are examined.

\section{Discussion}

As can be seen from the tables, the differences between the control sample and any teacher are higher than between the authors, which points to the impact being due to the method rather than the style of an individual teacher. It can also be seen that the data in Table 4 is very similar to that in Table 3 , so no comparative analysis has been conducted.

Using Table 3 and the mean values for Groups A, B and $V$ compared to the Control Group, the results show that more students experienced interest, confidence, enjoyment, calmness, activity, engagement joy and (to a lesser extent) desire to work at the lesson during the TAP workshops than did the control group in their usual school lessons. Class $B$ also registered more concern at not keeping pace with the teacher, and more irritation with other students who behaved in ways that interfered with the process of the lesson.

Nearly 3 times as many children fell confidence (item 2) during the TAP lesson, which reflects the actualization of the OK-OK life position.

$32 \%$ and $87 \%$ of the children, respectively, felt "calm" (item 4). Moreover, fear decreased from $17 \%$ to $3 \%$, and anger at the teacher from $12 \%$ to $5 \%$. We interpret this as a result of providing a higher emotional security at TAP lessons (protection against belittling, destructive group criticism, ridicule of the classmates in the case of an incorrect answer during the lesson, etc.).

The desire to work at the lesson (item 10) has increased, as well as the activity per se (item 5) (according to subjective self-evaluation of the students) from 26 to $80 \%$. However, the reasons for a higher level of passivity compared with the control group are not so clear. We wonder if this is connected with a greater level of comprehension of passive behaviour. It is remarkable that this parameter is highest in a correctional class, in both subgroups. 


\begin{tabular}{|c|c|c|c|c|c|c|}
\hline & Group Name & $\begin{array}{l}\text { Control } \\
\text { Group }\end{array}$ & Class "B" & Class “G” & $\begin{array}{l}\text { Class "V" } \\
\text { Correct- } \\
\text { ional } \\
\text { Class }\end{array}$ & $\begin{array}{l}\text { Mean } \\
\text { Values for } \\
\text { all Groups } \\
(B+G+V)\end{array}$ \\
\hline & number of children & 19 & 11 & 14 & 6 & 31 \\
\hline \multicolumn{7}{|c|}{ Increased } \\
\hline 1 & interest & 51 & 100 & 93 & 100 & 97 \\
\hline 2 & confidence & 31 & 91 & 100 & 77 & 92 \\
\hline 3 & enjoying the lesson & 39 & 82 & 93 & 50 & 81 \\
\hline 4 & calmness & 32 & 91 & 100 & 50 & 87 \\
\hline 5 & activity & 26 & 86,5 & 75,2 & 77 & 80 \\
\hline 6 & engagement & 24 & 100 & 100 & 33 & 87 \\
\hline 7 & $\begin{array}{l}\text { concerned at not keeping } \\
\text { pace with the teacher or } \\
\text { the class }\end{array}$ & 11,3 & 18,5 & 11,5 & 33 & 18 \\
\hline 8 & $\begin{array}{l}\text { irritation with those who } \\
\text { interfere with listening to } \\
\text { the teacher, with } \\
\text { participation in the lesson }\end{array}$ & 14 & 55 & 14 & 50 & 36 \\
\hline 9 & joy & 31 & 91 & 93 & 77 & 89 \\
\hline 10 & $\begin{array}{l}\text { desire to work at the } \\
\text { lesson }\end{array}$ & 68 & 82 & 100 & 50 & 84 \\
\hline \multicolumn{7}{|c|}{ Decreased } \\
\hline 11 & fear & 17 & 9 & 0 & 0 & 3 \\
\hline 12 & anger at the teacher & 12 & 9 & 3,5 & 0 & 5 \\
\hline 13 & boredom & 13 & 0 & 18 & 33 & 14,5 \\
\hline 14 & reluctance to engage & 9 & 9 & 0 & 33 & 10 \\
\hline 15 & lack of confidence & 27 & 13,5 & 7 & 33 & 14 \\
\hline 16 & hopelessness & 8,9 & 4,5 & 14 & 33 & 14 \\
\hline 17 & $\begin{array}{l}\text { feeling upset because of } \\
\text { not coping }\end{array}$ & 21 & 22,5 & 14 & 0 & 14 \\
\hline 18 & passivity & 10 & 4,5 & 14 & 33 & 14 \\
\hline
\end{tabular}

Table 3: Data for the sub-groups of the assistant psychologist 


\begin{tabular}{|c|c|c|c|c|c|c|c|}
\hline & Group Name & $\begin{array}{l}\text { Control } \\
\text { Group }\end{array}$ & $\begin{array}{l}\text { Class } \\
\text { "A" }\end{array}$ & $\begin{array}{l}\text { Class } \\
\text { "B" }\end{array}$ & $\begin{array}{l}\text { Class } \\
\text { "G" }\end{array}$ & $\begin{array}{l}\text { Class } \\
\text { "V" } \\
\text { Correct- } \\
\text { ional } \\
\text { Class } \\
\end{array}$ & $\begin{array}{c}\text { In Total } \\
(A+B+G+ \\
\text { V) }\end{array}$ \\
\hline & number of children & 19 & 19 & 12 & 12 & 4 & 47 \\
\hline \multicolumn{8}{|c|}{ Increased } \\
\hline 1 & interest & 51 & 89 & 100 & 100 & 100 & 96 \\
\hline 2 & confidence & 31 & 74 & 92 & 67 & 100 & 79 \\
\hline 3 & enjoying the lesson & 39 & 74 & 92 & 83 & 75 & 81 \\
\hline 4 & calmness & 32 & 58 & 74 & 92 & 100 & 74 \\
\hline 5 & activity & 26 & 68 & 74 & 67 & 75 & 70 \\
\hline 6 & engagement & 24 & 58 & 100 & 67 & 67 & 72 \\
\hline 7 & $\begin{array}{l}\text { concerned at not keeping } \\
\text { pace with the teacher or } \\
\text { the class }\end{array}$ & 11,3 & 32 & 16 & 17 & 33 & 24 \\
\hline 8 & $\begin{array}{l}\text { irritation with those who } \\
\text { interfere with listening to } \\
\text { the teacher, with } \\
\text { participation in the lesson }\end{array}$ & 14 & 63 & 42 & 25 & 25 & 45 \\
\hline 9 & joy & 31 & 84 & 100 & 75 & 100 & 87 \\
\hline 10 & $\begin{array}{l}\text { willingness to work at the } \\
\text { lesson }\end{array}$ & 68 & 84 & 75 & 67 & 75 & 77 \\
\hline \multicolumn{8}{|c|}{ Decreased } \\
\hline 11 & fear & 17 & 5 & 0 & 0 & 0 & 2 \\
\hline 12 & anger at the teacher & 12 & 5 & 8 & 0 & 0 & 4 \\
\hline 13 & boredom & 13 & 11 & 0 & 8 & 10 & 10 \\
\hline 14 & reluctance to engage & 9 & 5 & 8 & 8 & 0 & 6 \\
\hline 15 & lack of confidence & 27 & 16 & 8 & 25 & 0 & 15 \\
\hline 16 & hopelessness & 8,9 & 1 & 8 & 8 & 0 & 4,4 \\
\hline 17 & $\begin{array}{l}\text { feeling upset because of } \\
\text { not coping }\end{array}$ & 21 & 21 & 16 & 0 & 0 & 12,6 \\
\hline 18 & passivity & 10 & 11 & 8 & 25 & 67 & 19 \\
\hline
\end{tabular}

Table 4: Data for the sub-groups of the educational psychologist 
Analysis of the responses provided to the sentencecompletion activity were scrutinised and a selection of answers are provided here:

- I've learned ... to understand the teacher. I've learned to think. To understand the other person. Respect myself. Not to be afraid of the teacher.

- I've found out that ... there are a lot of good people in the world. I've learned a lot of interesting things. All teachers are good. You can ask questions at the lesson ... I'm kind.

- I've found confirmation that ... learning is necessary ... that all teachers are very hardworking ... My sister is smart

- I've discovered that .... Our class is very intelligent ... psychology is a good lesson .... My thinking is good ...

- I was surprised that .... the teacher treats us so decently .... I received a mark of 5 .

- The most important thing for me was that ... the teacher is kind .... that teachers don't put bad marks to us .... that we played at the psychology lesson...

From our point of view, these answers reinforce the results in the tables and reflect that the classes have made the most powerful influence on the formation of the OK-OK life position and on the development of autonomous Adult thinking.

\section{Conclusion}

Role play, methodologically based on psychodrama and TA, appeared to be more effective compared to the traditional (in Russia) educational method, for the formation of the following skills and qualities:

- $\quad$ autonomous thinking

- OK-OK life position

- taking responsibility for the outcome of the learning

- positive learning motivation

- the predominance of positive motivation in comparison with negative motivation

It also enhances the efficiency of a student through:

- $\quad$ greater involvement of students in the learning process

- an atmosphere of emotional security

- deliberate and conscious acceptance of school rules by the students

- $\quad$ better understanding of the teacher (the ability to consider the situation from the teacher's perspective)
Ending the article, we would like to express our agreement with the conclusion reached by Corey (2000/2003), writing of group counselling, that "Personally, I favor integrating TA concepts and practices with Gestalt and psychodrama techniques. ... TA concepts can be brought to life by the enactment methods that are typical of psychodrama" (p. 449).

Marina Solomonovna Sokovnina is an Educational Psychologist at PMSSC of the Kirov district of St. Petersburg and can be contacted on sokovnina@rambler.ru

Viktor Nikolayevich Aleshin is Associate Professor in the Department of Psychology in SPbAPGE St. Petersburg.

\section{References}

Aleshin V.N. \& Sokovnina M S (2012) integration of Psychodrama and Transactional Analysis Methods in Psychological Support of the Participants of Educational Process. Published in: XVI International Scientific and Practical Conference "Practical Psychology Service in The System of Education": The Proceedings 316-325 [Алешин В.Н., Соковнина М.С. Интеграция методов психодрамы и транзактного анализа в психологическом сопровождении участников образовательного процесса. В сб. Опубликовано в: XVI международная научно-практическая конференция «Служба практической психологии в системе образования»: сборник материалов [] / Под общ. ред. Шингаева С. М. - СПб.: СПбАППО]

Aleshin, V.N. (2009) Psychodrama as an Innovational Teaching Method. The Study Guide. Saint Petersburg: SPbAPPO [Алешин В.H. 2009 Психодрама как инновационный метод обучения. Учебно-методическое пособие Санкт-Петербург, СПбАППО, ]

Berne, E. (1957) A Layman's Guide to Psychiatry. New York: Grove Press [Берн Э. Введение в психиатрию и психоанализ для непосвященных. 1991, СПб, Издательство международного фонда истории науки]

Corey, G. (2000) Theory and Practice of Group Counseling, $5^{\text {th }}$ edition, published in the English language by Wadswordth $(2000,1995,1990,1985)$ [Джеральд Кори . Теория и практика группового консультирования 2003, М.: Эксмо]

Kipper, David A (1986) Psychotherapy Through Clinical Role Playing New York: Brunner/Mazel [Киппер Д. Клинические ролевые игры и психодрама.1993, М Независимая фирма «класс»]

Goulding, M. \& Goulding, R. (1997) Changing Lives through Redecision Therapy New York: Brunner/Mazel [Гулдинг М., Гулдинг Р. Психотерапия нового решения. Теория и практика. Москва. Независимая фрирма «Класс» 
Kolb, D (1984) Experiental Learning New Jersey:

Prentice-Hall.

Leutz, G. (2008) Seines Leben auf der Szene zu spielen.[publisher untraced] [Лейтц Грете, Сыграть свою жизнь на сцене. - М, издательство Академический проект (2008)]

Marineau, R.F. (1989) Jakob Levy Moreno. Father of psychodrama, sociometry and group psychotherapy London: Tavistock/Routledge [Рене Ф. Марино. История доктора Джей Л. Морено - создателя психодрамы, социометрии и групповой психотерапии -2001 Москва, издательство «Класс»]

Moreno, Z.T. (1998) Psychodrama, Role Theory, and the Concept of the Social Atom, In: The Evolution of Psychotherapy. Existential and Humanistic Psychotherapy Volume 3 Edited by Jeffrey K. Zeig New York:

Brunner/Mazel, Publishers New York [Морено, 3. T.

Психодрама: ролевая теория и концепция социального атома.// Эволюция психотерапии. Экзистенциальногуманистическая психотерапия. Том $3 /$ Пер. с англ - М, Независимая фирма «Класс»]
Stewart I., \& Joines V. TA Today (1987) Nottingham: Lifespace Publishing [Стюарт Ян, Джойнс Вэнн.

Современный транзактный анализ. Социальнопсихологический центр, Санкт-Петербург, 1996]

Vopel, Klaus K. $(1993,1997)$ Materialen fur Gruppenleiter Salzhausen: iskopress, (deutsch) [Фопель K.

Психологические группы. Рабочие материалы для ведущего, Москва, издательство Генезис, 2000] 


\section{Appendix: An agreement on cooperation between teachers and students}

Note. This version of the contract between teachers and students is the result of the work of the fifth grade students. It is given as an example only and not for use elsewhere.

School is our second home. We spend part of our life here.

This document is created out of our desire to live in harmony, to respect and to understand each other. It is also based on understanding that we have a common goal - to achieve the best result by every student. To reach this goal, we, the teachers and the students, conclude the following agreement:

1. Teacher (teachers). We want to teach you and we are ready to give our time and energy for this. In order to teach you, we are ready to do the following:

1.1. Come to school on time.

1.2. Prepare educational material for the lesson and provide lessons according to the schedule.

1.3. Give knowledge taking into account the features of the class.

1.4. Check the homework and test papers and explain what the mistakes are.

1.5. Make verbal requests.

1.6. Answer the questions concerning the learning material (during the lesson and in extra classes).

1.7. Give the opportunity to improve the mark at the time set by the teacher or in extra classes).

1.8. Mark fairly.

1.9. Control discipline during a lesson.

1.10. Write on a blackboard clearly.

1.11. Take into account the health status of a student (state of eyesight, hearing, etc.) when choosing a place for them to sit in the classroom.

1.12. Recognize the right of students to make mistakes.

1.13. Punish fairly.

1.14. Care for school property.

For effective learning we want you to perform the following rules:

- respect the teacher,

- maintain discipline during the lesson,

- do your homework,

- treat your fellows and classmates with respect,

- $\quad$ help if I ask,

- comply with safety regulations in relation to yourselves and others,

- $\quad$ if something is not clear, then ask with your hand raised.

2. Student (students). I want to learn and I'm willing to devote time and to invest an effort to it. To achieve the result in learning and to graduate from school I'm ready to:

2.1. Come to school on time

2.2. Maintain discipline

2.3. Work at the lesson

2.4. Make notes in a notebook.

2.5. If anything is unclear to me, I will ask questions. 
2.6. If I can't cope with something, I will ask for help from parents, friends, etc.

2.7. Write the home task in a diary and do the homework.

2.8. Bring the second pair of shoes and equipment that is necessary for working on the subject at the lesson.

2.9. Maintain discipline and follow safety regulations.

2.10. I will work systematically to avoid irretrievable gaps in my knowledge.

2.11. Recognize the right of my classmates and teachers to make mistakes.

2.12. Care for school property.

In order to make us feel good in school, we want teachers to:

- respect the students,

- put marks into the class register for knowledge and not for behavior

- note our success in studying,

- write on the blackboard clearly

- not let the necessary punishment humiliate a student

- to punish those who are responsible for misdeeds and not the whole class,

- if the teacher needs to leave the classroom or to be absent, then s/he should find a substitute. 